\title{
PHOSPHORITES OF THE BRAZILIAN CONTINENTAL MARGIN, SOUTHWESTERN ATLANTIC OCEAN
}

\author{
José Gustavo Natorf de Abreu ${ }^{1}$, Iran Carlos Stalliviere Corrêa², \\ Norberto OImiro Horn Filho ${ }^{3}$ and Lauro Júlio Calliari ${ }^{4}$
}

\begin{abstract}
The existence of phosphate deposits in the Brazilian continental margin is known since the 1970's and 1980's after the Global Recognition of the Brazilian Continental Margin Program - REMAC Project (Programa de Reconhecimento Global da Margem Continental Brasileira - Projeto REMAC) a joint program to explore the Brazilian continental margin. Phosphate deposits were collected on the seamounts offshore the northeastern Brazilian margin. In the early 2000's, phosphate samples were taken incidentally by demersal fishing fleet in the southern Brazilian continental margin which contributed to the knowledge of these deposits in the southwestern Atlantic. This paper describes the mineralogy of the samples with scanning electron microscopy and X-ray diffraction. The new phosphate deposits in the Brazilian continental margin suggests a much wider phosphate distribution than imagined in the REMAC publications, thus representing a contribution to the effort of the Brazilian Government, through the Ministry of Mines and Energy, the Geological Survey of Brazil (CPRM), the Inter-ministerial Commission for the Resources of the Sea and the Marine Geology and Geophysics Program who together undertake a Program to the Evaluation of the Mineral Potential of the Brazilian Legal Continental Shelf (REMPLAC), whose goal is to conduct a further investigation of the mineral potential of the Brazilian Territorial Sea and Exclusive Economic Zone (EEZ).
\end{abstract}

Keywords: marine mineral resource, phosphate deposits, Rio Grande Terrace.

RESUMO. A existência de depósitos fostáticos na margem continental brasileira é conhecida desde as décadas de 1970 e 1980, graças ao Projeto de Reconhecimento Global da Margem Continental Brasileira (REMAC) quando fosforitas foram recolhidas sobre os montes submarinos da região Nordeste. No início dos anos 2000 , amostras foram obtidas incidentalmente pela frota pesqueira demersal na margem continental sul brasileira, as quais foram incorporadas como novas ocorrências, contribuindo para o conhecimento destes depósitos no Atlântico sul ocidental. Este trabalho descreve a mineralogia deste material amostrado a partir de análises realizadas com microscópio eletrônico de varredura e difratometria de raios X. A localização das novas ocorrências de depósitos fostáticos na margem continental brasileira sugere uma distribuição bem mais ampla desses recursos minerais marinhos do que se imaginava até as publicações do REMAC, representando, portanto, uma contribuição ao esforço do governo brasileiro, através do Ministério de Minas e Energia, do Serviço Geológico do Brasil, da Comissão Interministerial para os Recursos do Mar e do Programa de Geologia e Geofísica Marinha que, juntos, empreendem o Programa de Avaliação da Potencialidade Mineral da Plataforma Continental Jurídica Brasileira (REMPLAC), cuja meta é realizar estudos mais aprofundados sobre a potencialidade mineral do Mar Territorial Brasileiro e da Zona Econômica Exclusiva (ZEE).

Palavras-chave: recurso mineral marinho, depósitos fostáticos, Terraço do Rio Grande.

\footnotetext{
1 Universidade do Vale do Itajaí (LOG/CTTMar/UNIVALI), Geological Oceanography Laboratory, Center for Technology of Earth and Marine Sciences, Rua Uruguai, 458, Setor E2, P.0. Box 360, Centro, 88302-202 Itajaí, SC, Brazil. Phone: +55(47) 3341-7718 - E-mail: gabreu@univali.br

2 Universidade Federal do Rio Grande do Sul (CECO/IG/UFRGS), Department of Geodesy, Institute of Geosciences, Rua Bento Gonçalves 9500, Building 43125, P.0. Box 15.001, Bairro Agronomia, 91501-970 Porto Alegre, RS, Brazil. Phone: +55(51) 3308-9855 - E-mail: iran.correa@ufrgs.br

3 Universidade Federal de Santa Catarina (GCN/CFH/UFSC), Department of Geosciences, Graduate Program in Geography, Center for Philosophy and Humanities, Campus Universitário Trindade, 88040-970 Florianópolis, SC, Brazil. Phone: +55(48) 3721-9664 - E-mail: horn@cfh.ufsc.br

${ }^{4}$ Fundação Universidade Federal do Rio Grande (IG/LOG/FURG), Oceanographic Institute, Laboratory of Geological Oceanography, Av. Itália Km 8, P.0. Box 474, Campus Carreiros, 96201-900 Rio Grande, RS, Brazil. Phone: +55(53) 3233-6518 - E-mail: Icalliari@log.furg.br
} 


\section{INTRODUCTION}

\section{Phosphate in the marine environment}

Phosphorus is an essential element for the life processes of plants and animals, occurring with relative abundance on Earth as phosphate in three different depositional types: (1) guano - organic deposit with low economic importance; (2) aluminum phosphate - mineral with some economic importance; and (3) calcium phosphate - the most important natural phosphate mineral deposit with high economic importance.

Phosphate may be found either in the continent or in the marine environment. On the continent may be associated with igneous, sedimentary and metamorphic rocks, as an accessory in most cases. Local enrichment of phosphate minerals may occur depending on factors such as mineralogy of the primary rocks, hydrothermalism and weathering (Born \& Kahn, 1990). The marine environment is primarily a sedimentary deposit whose formation is related to the phosphorus inflow to the oceans (Baturin, 1982; Ruttenberg \& Berner, 1993 apud Schenau et al., 2000). Marine phosphorites were sampled for the first time during the dredging done by the Challenger Expedition (1873-1876) on the Agulhas Bank, in South Africa (Murray \& Renard, 1981 apud Bentor, 1980). Since then similar occurrences were recorded in several other places on the ocean bottom.

In addition to phosphorus inflow, the formation of phosphorite is also related to nitrogen inflow, both being supplied by upwelling currents and mechanisms involving organic matter and biogeochemical processes (Sheldon \& Riggs, 1990). In seawater, phosphate $\left(\mathrm{PO}_{4}^{-3}\right)$ is suspended or dissolved in organic and inorganic forms. It is transported to the marine environment through river and underground inflow, volcanic and hydrothermal activity, rainfall, glacial discharges, coastal abrasions and even by the cosmic dust present on the Earth surface. Phosphate can also occur as guano and excretion of other marine organisms (Baturin, 1982).

The phosphate cycle in the ocean starts with the supply to the oceans, continues with the initial assimilation by phytoplankton organisms and transfers to the food chain of fish and marine mammals (Baturin, 1982). Finally, with the excretion and posterior deposition on the sediments, the phosphate becomes available to form phosphorite. Once recycled, through the metabolism of organisms and the action of bacteria and/or enzymes that decompose organic matter, phosphorus is returned to the environment and "re-mineralized" along with other nutrients, in upwelling zones (Brown et al., 1995).

Currently, the largest and most important upwelling zones in the world are located on the eastern edges of ocean basins where significant phosphate deposits occur. Burnett \& Riggs (1989) described important phosphogenesis events on the west coast of the United States associated with upwelling currents and bathymetry, favorable conditions accounted for in the model, for the time of upper Oligocene and the Quaternary.

These natural processes, responsible for the supply and concentration of phosphorus in the marine environment, result in an enrichment of up to $80 \%$ of this element in marine phosphate rocks, predominantly sedimentary, which are then called phosphorites. Under the assessment of the Program to the Evaluation of the Mineral Potential of the Brazilian Legal Continental Shelf (REMPLAC), the geological mapping of phosphorite deposits was included among the activities that should reveal the mineral potential of the continental margin. The evaluation of potential phosphorus reserves on the Brazilian continental margin represents the incorporation of the data to the national reserves statistics, as well as production and marketing of phosphates, which are raw materials for a range of products used to manufacture fertilizers and in the chemical industry.

In addition to the research about the potential phosphate deposits on the Brazilian continental margin, this study will contribute to other branches of marine science that address paleoceanography, climate change and related sea level changes since phosphorite formation is related to upwelling processes; mechanisms that have been occurring along the geological time.

\section{Phosphorite: concept, origin and age}

Phosphorite is an authigenic sedimentary rock that contains varying amounts of phosphate (Notholt, 1980; Slansky, 1986), predominantly in the form of apatite and hydroxyapatite. Among these, francolite is considered the most common phosphate mineral originated by recent diagenesis in marine environments (McClellan, 1980). It may also constitute a fibrous variety of apatite, such as tricalcium phosphate of sedimentary origin. It displays a cryptocrystalline or amorphous structure, of sandy or clayey texture, usually associated with calcium and magnesium carbonates, iron and aluminum oxides and uranium traces. Phosphorites may occur as pebbles, nodules or crusts.

Phosphorite occurs at the edges of continental shelves and upper continental slopes, in middle and low latitude regions, with reduced terrigenous sedimentation (Burnett, 1977) and maximum depth of $1,000 \mathrm{~m}$ (Silva \& Mello, 2004). It may also occur on the top of ridges and submarine plateaus that work as barriers to the flow of cold bottom currents, rich in nutrients like phosphorus. In these places, upwelling currents are at lower depths prevailing heated and oxidized waters, decreasing the solubility of 
phosphorus by a lower pH. Hence, phosphorus precipitates and enriches the sediment (Kasakov, 1937 apud Menor et al., 1979).

Previous works have highlighted four large and important phosphorite provinces in the oceans:

- East Atlantic (Tooms \& Summerhayes, 1968; Dingle, 1970, 1971; Summerhayes, 1970, 1972; Baturin et al., 1973; Emery et al., 1975; Kharin \& Soldatov, 1975);

- West Atlantic (Pratt \& Thompson, 1962; Gorsline \& Milligan, 1963; Pratt \& Manhein, 1968; Pratt, 1968; Sheridan et al., 1969; Hathaway, 1971);

- Pacific, on the California coast (Emery \& Dietz, 1950; Uchupi \& Emery, 1963; D'Anglejan, 1967) and on the Chilean-Peruvian coast (Murray \& Renard, 1891; Niino \& Chamberlain, 1961; Baturin \& Petelin, 1972; Burnett, 1974, 1977; Baturin et al., 1973).

The largest ever recorded phosphorite occurrences in the continental shelf of Morocco, although the results have been published only in brief communications (Baturin, 1969, 1971; Bremner, 1980).

The theories on the formation of phosphorite consider direct match precipitation through chemical interactions in saturated phosphate solutions and the metasomatic replacement of preexisting carbonate deposits, becoming apatite. This hypothesis is the most probable to explain phosphorite formation, however, whatever the reactions involved, the formation of the deposits is strongly dependent on the availability of phosphorus in the marine ecosystem. Besides the phosphate material, non-phosphate components are present in the mineralogical composition of marine phosphorite, which also proves its autochthonous origin. Glauconite and shells of foraminifera are observed in some concretions; however, the presence of non-phosphate components depends on environmental characteristics and adjacent sediments.

The process of phosphorite origin can be influenced by specific physic-chemical conditions prevailing during periods of transgression and regression. Transgressive periods are more favorable due to increased precipitation of solids and soluble compounds derived from higher productivity, the presence of more stagnant and phosphorus saturated basins and water background with minimum levels of 02 (Fischer \& Arthur, 1977; Sheldon, 1980), characteristic of these periods.

Phosphatization begins with the accumulation of precipitation in small nucleus that also corresponds to the beginning of apatite formation (Baturin, 1971). Kolodny (1980), Baturin (1971 and 1988), Glenn \& Arthur (1988), and Burnett \& Riggs (1989) described that phosphatization may have biogenic remains, such as foraminifera, fish bones and teeths with consequent formation of microcrystalline fluorapatite. The presence of debris from clam shells, corals, sea urchins and various other marine organism groups, partially or completely replaced, are examples of materials which can pass through the replacement process (Burnett \& Riggs, 1989). A second phase is the enrichment and mechanical concentration through the reworking of primary deposits during a later regression. The higher energy and more oxidizing environment, prevails accumulation of rich nodules with glauconite, dolomite and other iron oxides (Baturin, 1971; Kolodny, 1980; Baturin, 1988; Glenn \& Arthur, 1988; Burnett \& Riggs, 1989). In shallower waters, the fine carbonate sediments are the ideal nucleus for the apatite crystallization (Stum \& Leckie, 1977 apud Burnett \& Riggs, 1989).

Dating performed from the ${ }^{67} \mathrm{Sr} /{ }^{66} \mathrm{Sr}$ ratio suggest different ages for the start of the phosphogenesis ranging between 29.8 and 3.4 Ma BP (Jarvis et al., 1994). This variability depends on the formation site and the variation of the local concentrations of phosphorus, calcium and fluorine that make up the phosphorites. In Namibia, the age of phosphorite pellets was determined as middle Miocene and even Pleistocene (0.4 Ma BP) while, in the desert of Sechura, Peru, the ages were about $8.9 \mathrm{Ma}$ BP. The process of phosphatization in Cape Province in South Africa has been occurring recently, during the Pleistocene and the Holocene, although the carbonate matrix has formed, according to Jarvis et al. (1994), between the Miocene and the Pliocene (18.5 and 3.4 Ma BP).

The phosphorite studied in Brazil by Klein et al. (1992, 1993) were aged $32.8 \pm 6.4$ Ma BP placing the samples in the Oligocene. In addition to the radiocarbon dating of the samples collected recently, other chemical and mineralogical analyses must be performed to correlate the occurrences on the Brazilian continental margin to other regions of the world where phosphorite is formed.

\section{Phosphorite occurrences in Brazil}

In Brazil, the occurrence record of marine phosphorite is small. The environmental conditions for phosphorite formation should be better characterized and further detailed in order to evaluate more carefully this mineral resource on the Brazilian continental margin.

The largest phosphorite occurrences in the oceans are related to areas influenced by strong upwelling, which is more pronounced on the western margins of the continents (Baturin, 1971). However, Riggs \& Sheldon (1990) model suggested that the Brazilian coast could present favorable conditions for phos- 
phogenesis. So far, occurrences of phosphate deposits are cited by Millimann \& Amaral (1974); Melo et al. (1978), Guazelli \& Costa (1978), Menor et al. (1979), Schobbenhaus (1984) and Santana (1999), in works carried out on the terraces and submarine plateaus in northeastern Brazil. Klein et al. (1992) were the first to describe evidences of phosphorite deposits in samples from the Rio Grande Terrace (RS), in southern Brazil.

Samples collected accidentally by the fishing fleet, between 200 and $800 \mathrm{~m}$ deep, offshore the states of Rio Grande do Sul, Santa Catarina and Paraná during the Program of the Sustainable Potential of Living Resources of the Exclusive Economic Zone REVIZEE (1997 to 2000), suggest a possible wider distribution of the phosphate deposits on the southern Brazilian continental margin, added to the occurrences on the Brazilian northeastern continental margin.

The samples described in this study were obtained in the continental margin close to the Florianópolis Shelf and Rio Grande Terrace, located between the southern Santa Catarina and northern Rio Grande do Sul. Florianópolis Shelf presents subprovinces of the outer continental shelf and upper continental slope that appear as protruding features of the continental margin as demonstrated by the broad curvature of the isobaths. Figure 1 shows the location and distribution of phosphorite samples collected in the region, based on the study of Abreu et al. (2005).

The relief is extremely irregular in some specific sectors of this continental margin, as indicated by an echosounder record obtained in 1997 on board the survey vessel Diadorim, during REVIZEE Program (REVIZEE, 1997), whose sonogram shows sharp peaks of $12 \mathrm{~m}$ high (Fig. 2).

Data collected during REVIZEE Program were published by Pinho et al. (2011) suggesting the presence of phosphorite in certain areas of the continental shelf and continental slope of the southern Brazilian region. The study took into account the backscattering observed in the $38 \mathrm{kHz}$ echosounder records that indicate high hardness and compaction of the seafloor. The irregular morphology and the high backscattering of the seafloor indicate the compact nature of the seabed that may be related to the presence of phosphorite crusts, as evidenced by the samples collected in this area. Table 1 shows the location of the sampling stations and the results of petrographic analyses performed with this material.

\section{Mineralogical analysis}

The mineralogical composition of the collected samples was determined by X-ray diffraction and thin sections were analyzed by scanning electron microscope (SEM).
The main components were apatite, calcite and dolomite, derived from the replacement of calcium by the magnesium present in the seawater, through a diagenetic process, and quartz, which is the only mineral present in all samples. Among the phosphate minerals, carbonate fluorapatite and hydroxyapatite predominated in the samples, which were probably formed by carbonate replaced by phosphate and due to the high ionic affinity between fluorine and phosphorus. Other minerals identified by $\mathrm{X}$-ray were goethite, witherite, phillipsite, baryte and carbonate fluorapatite, which are associated with the processes of replacement and/or adsorption of the elements on the phosphate rocks. Figure 3 shows the diffractograms of AM-01, AM-04, AM-06 and AM13 samples, indicating the main minerals contained in them. The AM-12 mineralogical analysis performed by SEM (Fig. 4A) indicated the presence of quartz, apatite, glauconite, and dolomite wrapped in a phosphate matrix (Fig. 4B).

The mineralogical analysis of sample AM-13 (Fig. 5) indicated the presence of sediment well sorted, grains of quartz and apatite and traces of foraminifera and ostracods microfossils, confirming the authigenic origin of the phosphorite. The carbonate matrix is replaced by the phosphate matrix to the extent of the phosphatization process. Figure 5 shows the contact between the phosphate and carbonate matrix, besides of quartz, glauconite, apatite, dolomite and goethite. The phosphatization process that involves the replacement of biogenic calcium carbonate $\left(\mathrm{CaCO}_{3}\right)$ by phosphate $\left(\mathrm{PO}_{4}^{-3}\right)$ was discussed in Romankevich \& Baturin (1972) and Baturin (1982). According to Slansky (1986), this process is relatively common in the genesis of phosphorite.

\section{DISCUSSION AND CONCLUSION}

The phosphorite samples collected on the surface of the Florianópolis Shelf and Rio Grande Terrace indicates that this mineral occurs in the Northeast region of Brazil as well as the southern continental margin. Acoustic backscattering records obtained and analyzed during the REVIZEE Program indicated the existence of a submarine floor quite compacted and hardened corroborating the possibility of a more significant occurrence of phosphorite at the outer edge of the Florianópolis Shelf and Rio Grande Terrace, prominent features of the southwestern Atlantic ocean.

Menor et al. (1979) described the occurrence of phosphorite on the Ceará and Rio Grande do Norte plateaus in northeastern Brazil. The authors correlated the phosphorite formation to the circulation of cold deep waters, rich in phosphorus and other nutrients that upon meeting the submarines highs and plateaus these waters are pushed upwards causing upwelling. The phos- 


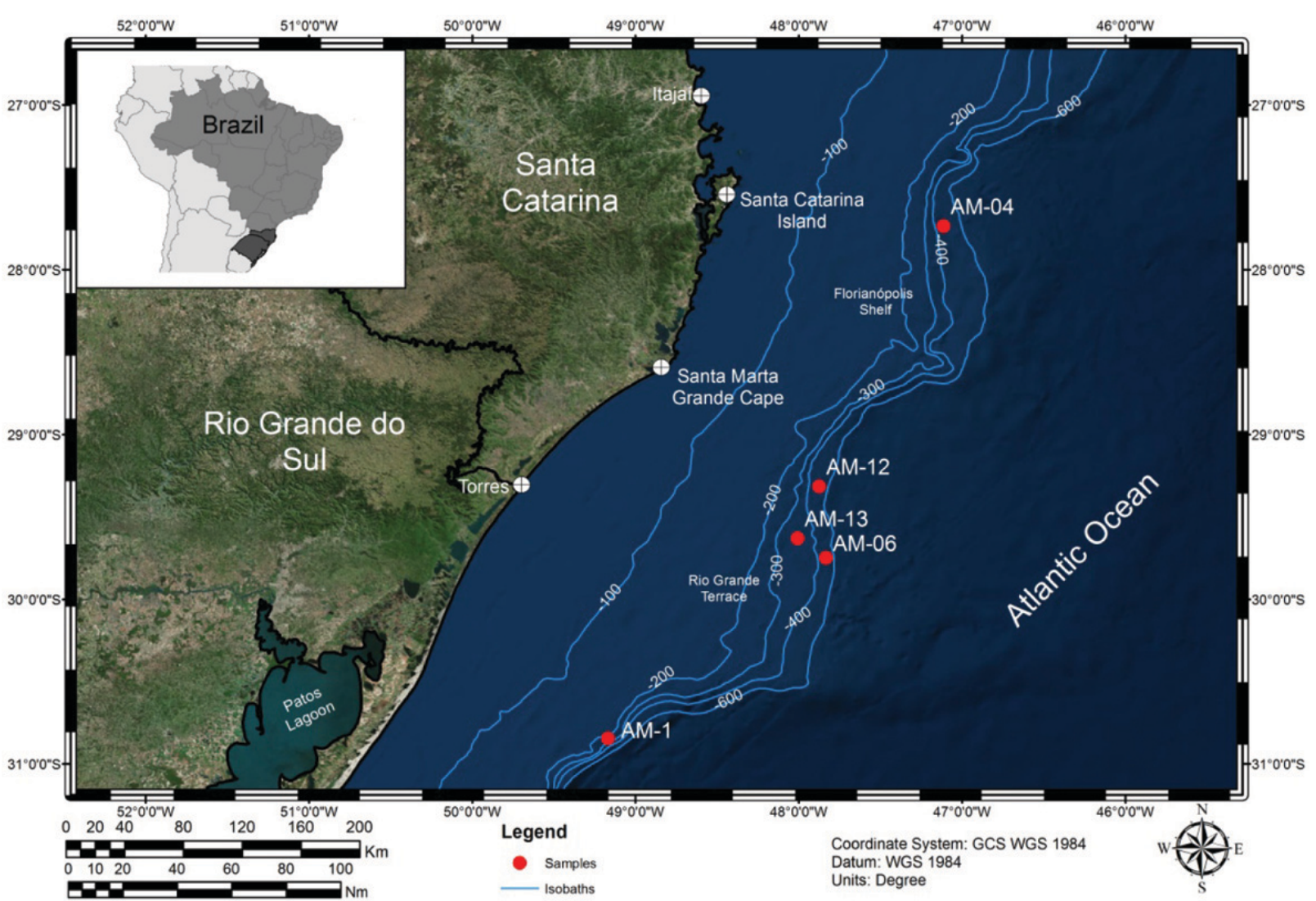

Figure 1 - Location of the sites where phosphorite samples were collected during various research projects developed in the South region of Brazil, modified from Abreu et al. (2005). Datum WGS 1984.

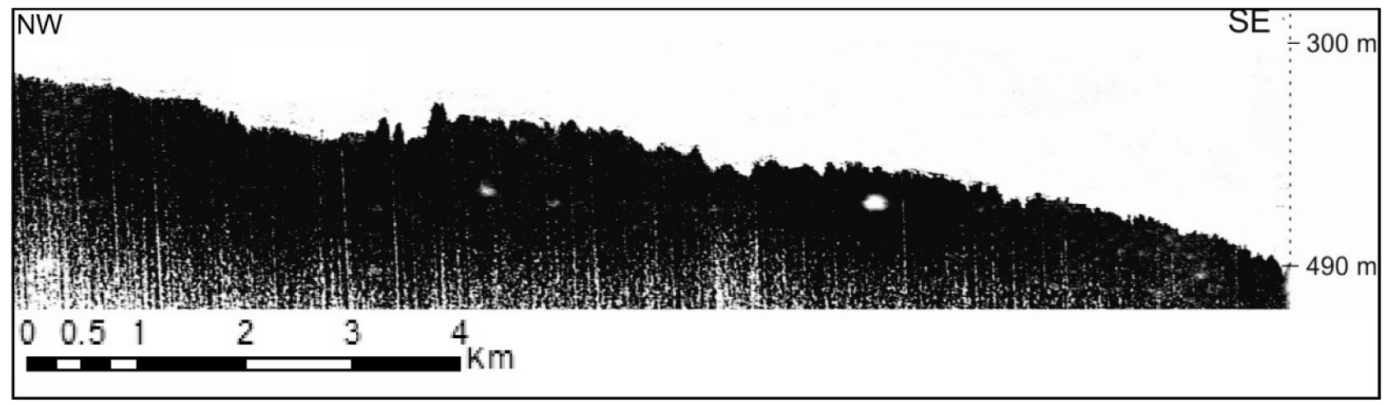

Figure 2 - Echogram obtained on board the survey vessel Diadorim during REVIZEE Program (REVIZEE, 1997).

phate present in the water precipitates inorganically due to decreased solubility of lower pH and oxidizing environment, upon reaching shallower and warmer areas (Kasakov, 1937 apud Menor et al., 1979). The Florianópolis Shelf and Rio Grande Terrace are located on the southern continental margin of Brazil strongly influenced by different water masses causing gradients of temperature, salinity and dissolved $\mathrm{O}_{2}$ concentration, among other oceanographic parameters. The South Atlantic Central Water -
SACW (Sverdrup et al., 1942), that moves towards south southwest following the continental shelf break and continental slope, between 200 and $500 \mathrm{~m}$ deep, is rich in nutrients and oxygen, and may have seasonal flows toward the continental shelf (Castro Filho \& Miranda, 1998) favoring the upwelling occurrence (Pereira et al., 2009). The region is also influenced by the Malvinas current that moves towards north northeast and is responsible for the supply of inorganic nutrients to shallower regions, 
Table 1 - Geographical position and main components of the analyzed samples.

\begin{tabular}{|c|c|c|c|c|c|}
\hline Sample & Lat. (S) & Long. (W) & Depht (m) & $\begin{array}{c}\mathrm{P}_{2} \mathrm{O}_{5} \\
(\%) \text { concentration }\end{array}$ & Main components \\
\hline AM-01 & $31^{\circ} 02.138^{\prime}$ & $49^{\circ} 22.346^{\prime}$ & 310 & - & $\begin{array}{c}\text { Quartz, Dolomite, Goethite, } \\
\text { Carbonate Fluorapatite, } \\
\text { Hydroxyapatite }\end{array}$ \\
\hline AM-04 & $27^{\circ} 44.140^{\prime}$ & $47^{\circ} 06.787^{\prime}$ & 530 & 5.39 & $\begin{array}{c}\text { Dolomite, Quartz, Goethite, } \\
\text { Carbonate Fluorapatite, } \\
\text { Hydroxyapatite }\end{array}$ \\
\hline AM-06 & $29^{\circ} 44.825^{\prime}$ & $47^{\circ} 49.989^{\prime}$ & 495 & 1.19 & $\begin{array}{c}\text { Quartz, Dolomite, } \\
\text { Goethite, Phillipsite, } \\
\text { Baryte }\end{array}$ \\
\hline AM-12 & $29^{\circ} 18.864^{\prime}$ & $47^{\circ} 52.500^{\prime}$ & $420-490$ & 3.94 & $\begin{array}{c}\text { Quartz, Phillipsite, Baryte, } \\
\text { Carbonate Fluorapatite, } \\
\text { Chlorapatite }\end{array}$ \\
\hline $29^{\circ} 37.708^{\prime}$ & $48^{\circ} 00.499^{\prime}$ & $350-380$ & 2.34 & $\begin{array}{c}\text { Dolomite, Quartz, } \\
\text { Phillipsite, Goethite, } \\
\text { Carbonate Fluorapatite }\end{array}$ \\
\hline
\end{tabular}
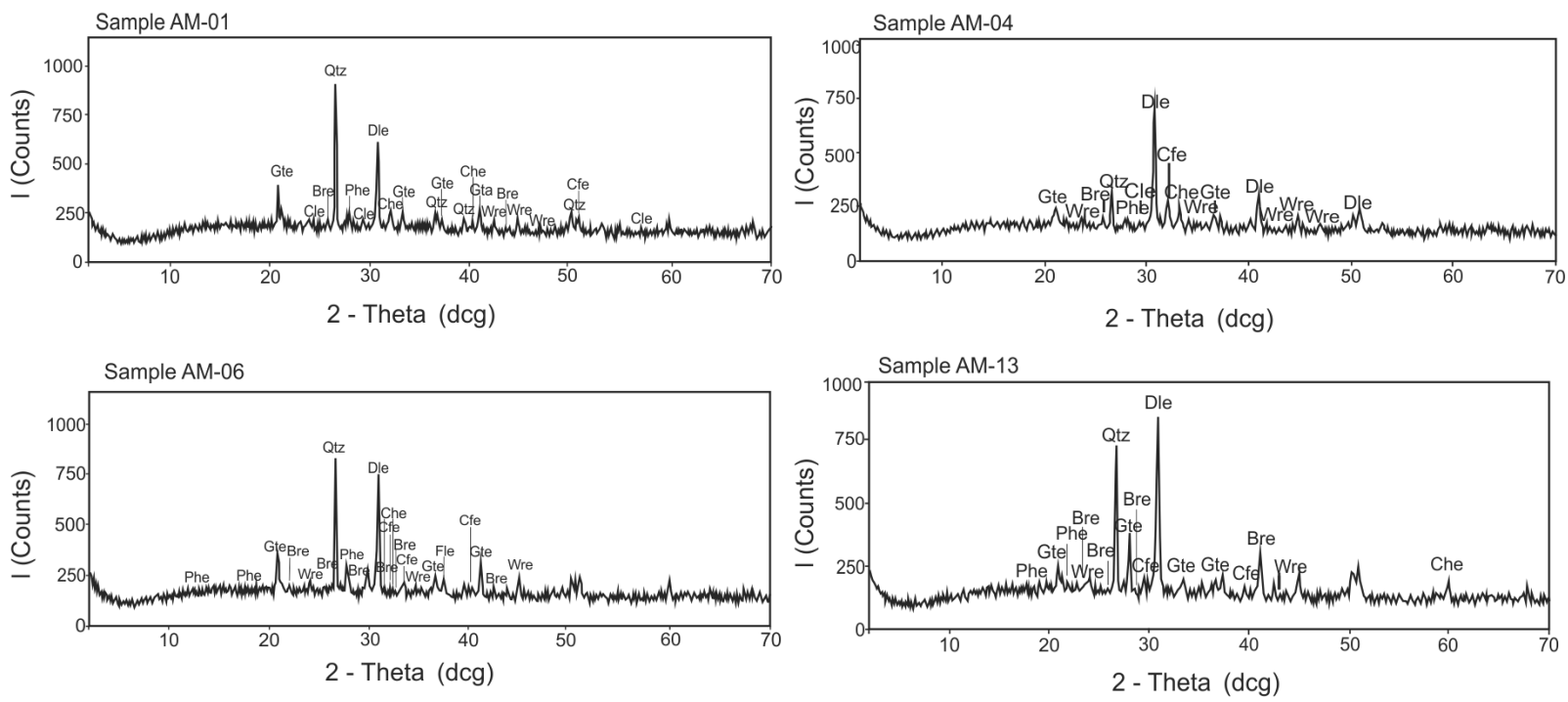

$\begin{array}{ll}\text { Qtz - Quartz } & \text { Phe - Phillipsite } \\ \text { Dle - Dolomite } & \text { Gte - Goethite } \\ \text { Wre - Witherite } & \text { Cle - Calcite }\end{array}$

Bre - Baryte

Cfe - Carbonate Fluorapatite

Che - Carbonate Hydroxyapatite

Figure 3 - X-ray diffractogram of AM-01, AM-04, AM-06, and AM-13 samples indicating the main minerals present.

close to the mainland. The bathymetry of the Florianópolis Shelf and Rio Grande Terrace, associated with the wind regime and seasonal flows, favors the formation of upwelling phenomenon that is responsible for the increase in primary biological productivity, due to the supply of nutrients and consequently, the accumulation of limestone bioclasts, fish bones and other marine organisms.
Microfossils of foraminifera and ostracods observed in one of the blades attest the association between phosphorite formation and bioclasts. The limestone matrix identified confirms the relationship of carbonate, which may originate from the dissolution of calcareous bioclasts, under phosphatization processes. The authigenesis was also suggested by occurrence of glauconite in the 


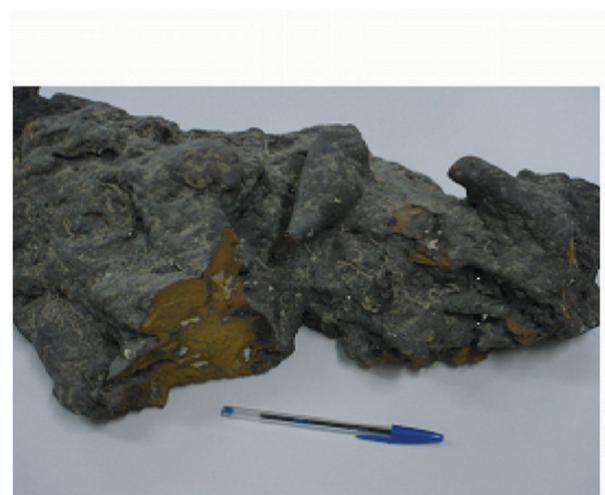

A

Figure 4 -Macroscopic sample AM-12 (A) and its thin section (B). Note the presence of carbonate dolomite in the phosphate matrix and other accessory minerals such as quartz and glauconite.

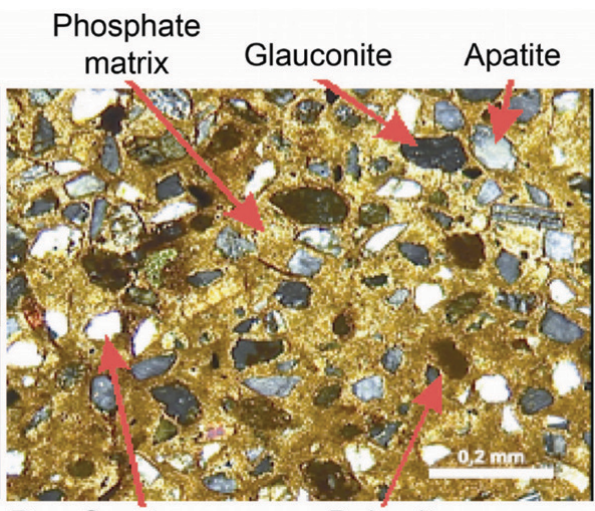

B Quartz

\section{Dolomite}

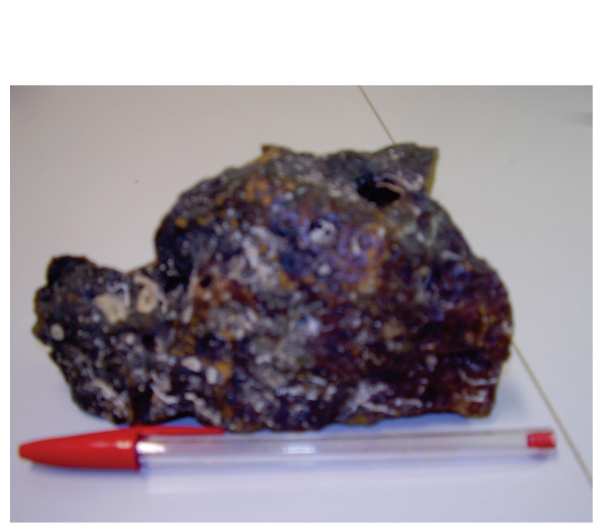

A

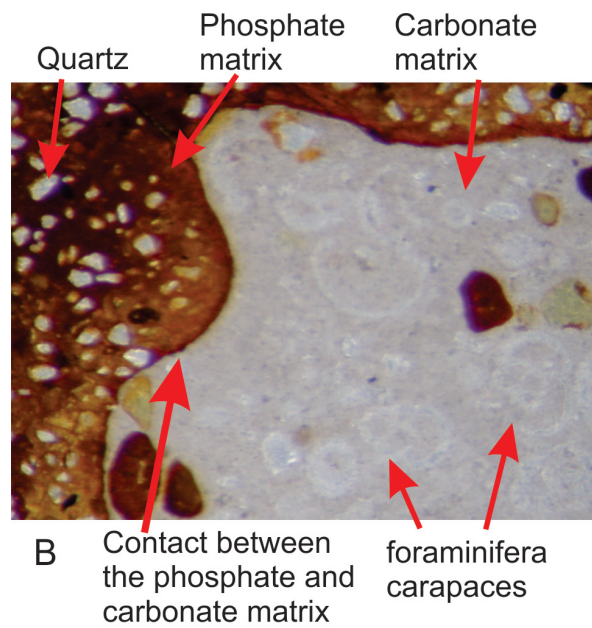

Figure 5 - (A) Macroscopic aspect of the AM-13 sample obtained in the vicinity of Santa Marta Grande cape (SC); and (B), Thin section showing the contact between the phosphate and carbonate matrix with foraminifera carapace, being identified quartz and apatite, traces of microfossils (foraminifera and ostracods).

phosphate deposit. In addition to this mineral, quartz, dolomite and goethite were also identified, indicating a diagenetic origin for phosphorite whether conglomerate or nodular.

The age of the analyzed phosphorite samples was not determined and, therefore, cannot be compared with the samples described by Klein et al. (1992) and Klein etal. (1993) collected from the continental slope of Rio Grande do Sul, with respect to the time and environmental conditions of formation. However, the lower levels of $\mathrm{P}_{2} \mathrm{O}_{5}$ determined for the samples collected from the Rio Grande Terrace and Florianópolis Shelf compared to the samples collected farther south may be related to the lower rate of phosphorus inputs from the continent in this area compared to the other region. The Rio Grande do Sul continental drainage network, before being isolated by the closure of the lagoon-barrier depositional system of Pleistocene and Holocene (Villwock \& Tomazelli, 1995; Tomazelli \& Villwock, 1996; Tomazelli et al., 2000) was reaching the ocean basin more significantly, when compared with the lower expression of Santa Catarina drainage. This may be responsible for a minor contribution condition and a reduced availability of phosphorus to the area where phosphorite is formed. Anyway, new geochronological and mineralogical analyses should be performed to correlate the phosphorite present on the surface of the Rio Grande Terrace and Florianópolis Shelf with that occurring in the Rio Grande do Sul continental slope and in other areas of the Brazilian continental margin.

Geological and geophysical surveys should be carried out in more detail in the short and medium term, to supply basic information to future projects. 


\section{ACKNOWLEDGEMENTS}

The authors are thankful to the Center for Research and Management of Fishery Resources on the Southeast and South Coast - CEPSUL/ICMBio for supplying the echo bathymetric data obtained in 1997 by the Diadorim research vessel.

To Dr. Vitor Paulo Pereira of the Department of Mineralogy and Petrology of the Geosciences Institute (UFRGS), Ricardo Piazza Meireles and José Eloi Guimarães Campos from the X-ray Diffraction Laboratory $(\mathrm{UnB})$ for the preparation and description of the thin sections used in this study.

\section{REFERENCES}

ABREU JGN, MEIRELES RP \& BATISTA M. 2005. Fosforitas da margem continental brasileira. In: Congresso Brasileiro de Oceanografia, 2., Extended Abstracts... Vitória, ES, outubro de 2005. Associação Brasileira de Oceanografia (AOCEANO). CD-ROM.

BATURIN GN. 1969. Authigenic phosphorite concretions in recent sediments of the shelf of the southwest Africa. Dokl. Akad. Nauk SSSR., 183: 6 .

BATURIN GN. 1971. Stages of phosphorite formation on the ocean floor. Nature Phys. Sci., 232: 61-62.

BATURIN GN. 1982. Phosphorites on the sea floor: origin, composition and distribution. N.Y., Elsevier, 343 pp.

BATURIN GN. 1988. Disseminated phosphorus in oceanic sediments. A review. Mar. Geol., 84: 96-104.

BATURIN GN \& PETELIN VP. 1972. Phosphorite concretions on the shelf of Chile. Litol. Polezn. Iskop: 3.

BATURIN GN, SHISHKINA OV \& ROMANOV VI. 1973. On the bottom sediments, rocks and interstitial waters of the south-eastern sector of the North Atlantic. Morsk. Gidrofiz. Issled., 3: 62.

BENTOR YK. 1980. Phosphorites - the unsolved problems. In: BENTOR YK (Ed.). Marine Phosphorites - Geochemistry, Occurrence, Genesis. Tulsa, Oklahoma, USA, Soc. Econ. Paleont. Mineral. Spec. Publ., 29: 3-18.

BORN H \& KAHN H. 1990. Caracterização geológica e mineralógica voltada ao aproveitamento de jazimentos fosfáticos. In: Encontro Nacional de Rocha Fostática, 5., São Paulo, Proceedings... São Paulo: IBRAFOS, p. 213-233.

BREMNER JM. 1980. Concretionary phosphorites from SW Africa. The J. Geol. Soc. London, 137(6): 773-786.

BROWN J, COLLING A, PARK D, PHILLIPS J, ROTHERY D \& WRIGHT J. 1995. Seawater: its composition, properties and behaviour. 2 ed., Singapore: The Open University. 168 pp.
BURNETT WC. 1974. Phosphorite deposits from the sea floor off Peru and Chile: radiochemical and geochemical investigations concerning their origin. Ph.D. Thesis. Hawaii Institute of Geophysics, University of Hawaii, Honolulu, Hawaii. 164 pp.

BURNETT WC. 1977. Geochemistry and origins of phosphorite deposits from off Peru and Chile. Geol. Soc. Am. Bull., 88(6): 813-823.

BURNETT WC \& RIGGS SR (Eds.). 1989. Phosphate deposits of the world. Cambridge University Press. 464 pp.

CASTRO FILHO BM \& MIRANDA LB. 1998. Physical oceanography of the western Atlantic Continental Shelf located between $4^{\circ} \mathrm{N}$ and $34^{\circ} \mathrm{S}$. In: ROBINSON AR \& BRINK KH (Eds.). The Sea. New York, John Wiley $\&$ Sons, 2, p. 209-251.

D'ANGLEJAN B. 1967. Origin of marine phosphorite off Baja California, Mexico. Mar. Geol., 5(1): 15-44.

DINGLE RV. 1970. Preliminary geological map of part of the eastern Agulhas Bank, South African continental margin. Proc. Geol. Soc. London, 1663: 137.

DINGLE RV. 1971. Tertiary sedimentary history of the continental shelf off southern Cape Province, South Africa. Trans. Geol. Soc. S. Afr., 74: 173.

EMERY KO \& DIETZ RS. 1950. Submarine phosphorite deposits off California and Mexico. Calif. J. Mines. \& Geol., 46(1): 7-15.

EMERY KO, UCHUPI E, BOWIN CO, PHILLIPS J \& SIMPSON ESW. 1975. Continental margin off Western Africa: Cape St. Francis (South Africa) to Walvis Ridge (South-West Africa). Am. Assoc. Pet. Geol. Bull., 59(1): 3-59.

FISCHER AG \& ARTHUR MA. 1977. Secular variations in the pelagic realm. In: COOK HE \& ENOS P (Eds.). Deep-water Carbonate Environments. Soc. Econ. Paleont. Mineral. Spec. Publ. 25: 19-50.

GLENN CR \& ARTHUR MA. 1988. Petrology and major element geochemistry of Peru Margin phosphorites and associated diagenetic minerals: Authigenesis in modern organic-rich sediments. Mar. Geol., 80: 231-267.

GORSLINE DS \& MILLIGAN DB. 1963. Phosphatic deposits along the margin of the Pourtalès Terrace, Florida. Deep-Sea Res., 10(3): 259260

GUAZELLI W \& COSTA MPA. 1978. Ocorrência de fosfatos no Platô do Ceará. In: Ocorrência de fosforita e de nódulos polimetálicos nos platôs do Ceará e de Pernambuco. Rio de Janeiro. PETROBRAS, CENPES, DINTEP 3: 7-14.

HATHAWAY JC. 1971. Data file, continental margin program, Atlantic Coast of the United States, v. 2. Sample collection and analytical data. Woods Hole Oceanographic. Inst. Res., Ref. 71-15

JARVIS I, BURNETT WC, NATHAN Y, ALMBAYDIN FSM, ATTIA AKM, CASTRO LN, FLICOTEAUX R, HILMY ME, HUSAIN V, QUTAWNAH AA, 
SERJANI A \& ZANIN YN. 1994. Phosphorite geochemistry: State-of-theart and environmental concerns. Eclogae Geol. Helv., 87: 643-700.

KHARIN GS \& SOLDATOV AV. 1975. Lithologic features of the phosphorites of the Atlantic shelf of Africa. Litol. Polezn. Iskop. 2.

KLEIN AHF, GRIEP GH, CALLIARI LJ \& VILLWOCK JA. 1992. Ocorrência de Concreções fostáticas no Terraço do Rio Grande, RS. In: Congresso Brasileiro de Geologia, 37., Extended Abstracts... São Paulo, SP, Brazil, 1: 202-203.

KLEIN AHF, GRIEP GH, CALLIARI LJ \& VILLWOCK JA. 1993. Occurence of phosphate concretions on the Rio Grande Terrace, Brazil. In: IOCUN (Oalos) Programa Ciencia Oceánicas en Relación a los Recursos no Vivos (OSNLR), 1993, Porto Alegre, RS, Brazil.

KOLODNYY. 1980. Phosphorites. In: EMILIANIC (Ed.). The Sea. Willey, New York, v. 7., p. 981-1023.

MCCLELLAN GH. 1980. Mineralogy of carbonate fluorapatites. J. Geol. Soc. London, 137: 675-681.

MELO U, GUAZELLI W \& COSTA MPA. 1978. Nódulos polimetálicos, com núcleo de fosforitas, no Platô de Pernambuco. Rio de Janeiro. PETROBRAS, CENPES, DINTEP, Série Projeto REMAC 3: 15-32.

MENOR EA, COSTA MPA \& GUAZELLI W. 1979. Depósitos de fosfato. Rio de Janeiro. PETROBRAS, CENPES, DINTEP 10: 51-72.

MILLIMANN JD \& AMARAL CAB. 1974. Economic potential of Brazilian continental margin sediments. In: Congresso Brasileiro de Geologia, 28., 1974, Proceedings... Porto Alegre, RS, Brazil, 3: 335-344.

MURRAY J \& RENARD A. 1891. Deep-sea deposits. Report of the "Challeger" Expedition, London, p. 1873-1876.

NIINO H \& CHAMBERLAIN TK. 1961. The formation of submarine phosphorite deposits off the coast of Japan and Peru. In: Pacific Sci. Congr., 10., 1961, 1, p. 382.

NOTHOLT AJG. 1980. Economic phosphatic sediments: mode of occurrence and stratigraphical distribution. J. Geol. Soc., 137(6): 793-805.

PEREIRA MD, SCHETTINI CAF \& OMACHI CY. 2009. Caracterização de feições oceanográficas na plataforma de Santa Catarina através de imagens orbitais. Brazilian Journal of Geophysics, 27(1): 81-93.

PINHO MP, MADUREIRA LSP, CALLIARI LJ, GRIEP GH \& COOKE CV. 2011. Depósitos fosfáticos marinhos na costa sudeste e sul do Brasil: potenciais áreas de ocorrência identificadas com dados de retroespaIhamento acústico do fundo e sedimentológicos analisados sobre mapa batimétrico 3D. Brazilian Journal of Geophysics, 29(1): 113-126.

PRATT RM. 1968. Atlantic continental shelf and slop: physiography and sediments of the deep sea basin. U.S. Geol. Survey Prof. Paper 529-B.

PRATT RM \& MANHEIN FT. 1968. The relation of manganese to phosphorite concretions on the Blake Plateau. Trans. Am. Geophys. Union, 48(1).
PRATT RM \& THOMPSON SL. 1962. Report on Atlantic Cruises 280281. Woods Hole Oceanographic. Inst., Ref., 62-40.

REVIZEE. Programa de Avaliação do Potencial Sustentável de Recursos Vivos na Zona Econômica Exclusiva. 1997. Projeto de Prospecção de Peixes Demersais com Armadilhas e Espinhéis Verticais. Instituto Brasileiro do Meio Ambiente e dos Recursos Naturais Renováveis (IBAMA), Centro de Pesquisa e Extensão Pesqueira das Regiões Sudeste e Sul (CEPSUL). Relatório de Cruzeiro 01/97.

RIGGS SR \& SHELDON RP. 1990. Paleoceanographic and paleoclimatic controls of the temporal and geographic distribution of upper Cenozoic continental margin phosphorites. In: BURNETT WC \& RIGGS SR (Eds.). Phosphate deposits of the world. Neogene to modern phosphorites. Cambridge University Press, v. 3. p. 207-222.

ROMANKEVICH YA \& BATURIN GN. 1972. On the composition of organic matter of the phosphorites of the shelf of Southwest Africa. Geokhimiya. 6.

SANTANA Cl. 1999. Mineral resources of the Brazilian continental margin and adjacent oceanic regions. In: MARTINS LR \& SANTANA CI (Eds.). Non-Living resources of the southern Brazilian coastal zone and continental margin. IOC-UNESCO/OSNLR/SERG. p. 15-25.

SCHENAU SJ, SLOMP CP \& DE LANGE GJ. 2000. Phosphogenesis and active phosphorite formation in sediments from the Arabian Sea oxygen minimum zone. Mar. Geol., 169: 1-20.

SCHOBBENHAUS C. 1984. Geologia do Brasil. Texto explicativo do mapa geológico do Brasil e da área oceânica adjacente incluindo depósitos minerais. Escala 1:2.500.000. In: SCHOBBENHAUS C, CAMPOS DA, DERZE GR \& ASMUS HE (Eds.). Geologia do Brasil. Brasília, Departamento Nacional de Produção Mineral, 1984. p. 57-91.

SHELDON RP. 1980. Episodicity of phosphate deposition and deep ocean circulation - a hypothesis. In: BENTOR YK (Ed.). Marine Phosphorites - Geochemistry, Occurrence, Genesis. Tulsa, Oklahoma, USA, Soc. Econ. Paleont. Mineral. Spec. Publ.. 29: 239-247.

SHERIDAN RE, SMITH JP \& PURDNER J. 1969. Rock dredges from Blake escarpment near Great Abaco Canyon. Bull., Am. Assoc. Pet. Geol., 53(12): 2551-2558.

SILVA CG \& MELLO SL. 2004. Recursos Não-Vivos. In: 0 Mar no Espaço Geográfico Brasileiro. Coleção Explorando o Ensino: Geografia. Ministério da Educação, Secretaria de Educação Básica, 8: 160-194.

SLANSKY M. 1986. Geology of Sedimentary Phosphates. New York: Elsevier Science Publishing. 210 pp.

SUMMERHAYES CP. 1970. Phosphate deposits on the northwest African continental shelf and slope. Ph.D. Thesis, University of London. $282 \mathrm{pp}$.

SUMMERHAYES CP. 1972. Geochemistry of continental margin sediments from the north-western Africa. Chem. Geol., 10(2): 137-156. 
SVERDRUP HU, JOHNSON MW \& FLEMING RH. 1942. The Oceans. Their physics, chemistry, and general biology. New York, Prentice-Hall, Inc., 1087 pp.

TOMAZELLI LJ, DILLENBURG SR \& VILLWOCK JA. 2000. Late Quaternary geological history of Rio Grande do Sul coastal plain, southern Brazil. Revista Brasileira de Geociências, 30(3): 474-476.

TOMAZELLI LJ \& VILLWOCK JA. 1996. Quaternary geological evolution of the Rio Grande do Sul coastal plain, southern Brazil. Anais da
Academia Brasileira de Ciências, 68: 373-382.

TOOMS JS \& SUMMERHAYES CP. 1968. Phosphatic rocks from the northwest African Continental Shelf. Nature, 218: 5148.

UCHUPI \& EMERY K0. 1963. The continental slope between San Francisco, California, and Cedros Island, Mexico. Deep-Sea Res., 10(4): 397-448.

VILLWOCK JA \& TOMAZELLI LJ. 1995. Geologia costeira do Rio Grande do Sul. Notas Técnicas, Porto Alegre, 8: 1-45.

Recebido em 2 outubro, 2012 / Aceito em 11 dezembro, 2013

Received on October 2, 2012 / Accepted on December 11, 2013

\section{NOTES ABOUT THE AUTHORS}

José Gustavo Natorf de Abreu graduated in Oceanography (FURG/1984), holds a Master in Marine Geology (LAGEMAR-UFF/1998) and PhD in Geosciences (UFRGS/2010). Currently, is a Professor of the undergraduate Oceanography at the Universidade do Vale do Itajai (UNIVALI). Develops research in geomorphology, sedimentology, marine geophysics and exploration of mineral resources of the sea.

Iran Carlos Stalliviere Corrêa graduated in Geology (UFRGS/1973), holds a Master in Geosciences (UFRGS/1979) and Doctor of Oceanology (University of Bordeaux I-France/1990). Currently, is a Professor of the Department of Geodesy and the Graduate Program in Geosciences at the Universidade Federal do Rio Grande do Sul (UFRGS). CNPq researcher 1D.

Norberto Olmiro Horn Filho graduated in Geology (UNISINOS/1979), holds a Master and PhD in Geosciences (UFRGS/1988 and 1997). Currently, is a Professor of the Department of Geosciences and Geography Graduate Program at the Universidade Federal de Santa Catarina (UFSC). CNPq researcher 2.

Lauro Júlio Calliari graduated in Oceanography (FURG/1975), holds a Master in Geosciences (UFRGS/1980) and PhD in Marine Science (College of William and Mary-Virginia Institute of Marine Science/1990). Currently, is a Professor at the Institute of Oceanography at the Universidade Federal do Rio Grande (FURG). CNPa researcher $1 \mathrm{C}$. 